\title{
The Ebre observatory - Its path to ionospheric research
}

\author{
J. Batlló $^{1, a}$ and D. Altadill ${ }^{* 2, a,}$
}

a'Observatori de l’Ebre, Universitat Ramon Llull, CSIC, Carretera de l’Observatori 8, E43520 Roquetes, Spain

\begin{abstract}
The Observatori de l'Ebre became operative in late 1904. From the beginning it was devoted to studying the influence of solar activity on Earth’s physical phenomena. Ionospheric studies should be, as they are, an important part of its research activity. This article reviews the development of ionospheric research at the observatory and the main contributions the Observatori has made to ionospheric science.
\end{abstract}

Keywords: Ebre observatory; Ionospheric research; URSI; Cost actions

\footnotetext{
*Corresponding author.

${ }^{1}$ Present address: Institut Geologic de Catalunya, Parc de Montjuic s/n, E-08038 Barcelona, Spain.

${ }^{2}$ Present address: Center for Atmospheric Research, University of Massachusetts, Lowell, MA 01854, USA.
} 


\section{Article Outline}

1. Historical background

2. The long way to ionospheric studies (1905-1955)

3. The ionospheric section

4. Summary and concluding remarks

Acknowledgements

References

\section{Historical background}

Observatori de l'Ebre (or in Spanish, Observatorio del Ebro), situated in Spain near the delta of the Ebro River in the small town of Roquetes, near Tortosa, was officially inaugurated on the occasion of the solar eclipse on 30 August 1905, just one hundred years ago. In fact, the decision to build the Observatory was made in the last years of the XIX Century and the proximity of the eclipse date accelerated its construction. The main instrumentation was already operating since September 1904. The Observatory was erected by the Society of Jesus, at its own expense. It is another attestation of the traditional interest of the Jesuits in natural sciences since the earliest days of its foundation in 1540 ([Udias, 2003] and [Alberca and Torta, 2002]) and the origin of its foundation should be placed, in time, in the background of the renewed interest of the catholic church in positive sciences stated in the "motu propio" of Pope Leo XIII published in March 1891 on the occasion of the inauguration of the Specola Vaticana.

The site of the new observatory was selected because of its proximity to the Jesuit Faculties of Philosophy and Theology (Collegio Maximo), already existing at that time in Tortosa. The direct cause of its origin is related to the interest of Jesuits for a solid basis on natural sciences as a part of the philosophical studies of their members. Following this line, it was decided to create, attached to the philosophy faculty, laboratories on biology, chemistry, and physics. They should perform a role similar to the classical "cathedras" and at the same time develop their own research. In modern terms, they should be something similar to small university departments. Clearly, the idea was really progressive at the end of the XIX century.

The chemistry and biology laboratories were created in 1906 and 1908, respectively, and moved to Barcelona in 1916, but the project of a physics institute was changed in favor of a geophysics observatory. The reason for the change was the selected director, Ricard Cirera (1864-1932), a Jesuit who had just returned from the Philippines, where he had been vice director and head of the magnetic section of the Manila Observatory, another well known and prestigious Jesuit center. He convinced his superiors that, given the available human, economic, and research resources and possibilities, this was an optimum choice. 
The main research topic of the observatory became not geophysics of the solid Earth, but the study of the relationships between solar activity and the variations of terrestrial magnetic and electric phenomena. It was the first research center in the world devoted specifically to this topic, now known as solar-terrestrial physics. This relationship was, at that time, a controversial topic (e.g., Nippoldt, 1904). The Ebre Observatory in pursuing this research, demonstrated its sincere desire to take a place at the cutting edge of natural sciences research of the time. It was coincident in time with the experiments of Marconi and the works of A.E. Kennelly and O. Heaviside postulating the existence of an ionized layer in the atmosphere. Going back to the original idea looking for a physics laboratory with some good research direction, it is clear that the projected observatory fulfilled the goal. The selection of the topic was also a personal choice of R. Cirera. He expressed his interest and ideas about it in the first "Memoire" of the Ebre Observatory (Cirera, 1906): "as barometric lows are in Manila easiest to interpret [...] due to the extremely regular variation of atmospheric pressure [...], we were thinking that, due to the regular daily variation of magnetic elements, it can be affordable the comparative study of its perturbations, even the smallest ones [...] with other physical phenomena".

It is clear that he did not know (as nobody else did) at that time that behind his argumentation, he was dealing with atmosphere ionization, but he showed he was ready to undertake the study. To afford the study of all these phenomena, he developed a program of observations that should cover all affected fields (Cirera, 1906): visual and spectroscopic daily surveys of the Sun were undertaken; geomagnetic field, telluric currents, and atmospheric electric potential continuous recording were set up; air conductivity, atmospheric ion contents and other secondary parameters were also measured. All this was completed with meteorological and seismic stations. The observation planning and instrumentation is accurately described in four memoranda published by the Observatory ([Cirera, 1906], [Balcells, 1908], [Merveille, 1908] and [García Mollà, 1909]). As stated before, the whole deployment was fully operative for the survey of the solar total eclipse of 30 August 1905 , the first milestone in the history of the observatory.

From that moment on, data and results were continuously collected and carefully analyzed and, as early as 1907, Cirera communicated to the French Academy of Sciences that "at Ebre Observatory it looks like it is possible to verify day by day the stated conditions of the influence of the Sun's activity on the terrestrial magnetism" (Cirera et Balcells, 1907).

\section{The long way to ionospheric studies (1905-1955)}

The outline of a general history of the Ebre Observatory is not the main topic of this paper, it has previously been reviewed in several articles ([Cardús, 1983], [Coulomb, 1983], [Batlló, 1995], [Alberca and Torta, 2002] and [Batlló and Roca, 2005]). Our main interest is to show how ionospheric studies were introduced at the observatory and their importance. It is worth noting that in the years following the founding of the Observatory, the quick evolution of the knowledge on the influence the Sun's activity has on terrestrial physics led the Observatory to concentrate 
on some particular problems. In 1920, the Jesuit Lluís Rodés (1881-1939) replaced Cirera as director of the center. One of the topics he introduced, which is of interest, was the study of magnetic storms and rapid variations of the magnetic field (e.g.: [Rodés, 1922], [Rodés, 1927a] and [Rodés, 1932]).

It is interesting to note that Rodés was really aware of the contemporary knowledge on the ionosphere. In his analysis about the simultaneity of magnetic storms (Rodés, 1927a) he already points to the necessity of taking into account the contributions of the ionized atmosphere. Also, he published two different editions of a popular science book titled "EI Firmamento" ([Rodés, 1927b] and [Rodés, 1939]). In the first edition is a description of the structure of Earth's atmosphere without any mention of an upper ionized layer. In contrast, the second edition explains this upper ionized layer, and even gives the principles of the vertical ionospheric sounder.

Another related topic that was studied during those years was the periodicity of the variations of the atmospheric electric potential field ([Bauer, 1922], [Bauer, 1924], [Bauer, 1925], [Puig, 1931] and [Rodés, 1933]). Daily variations and other short period regular variations carefully studied at the Observatory were directly connected with ionosphere dynamics.

All the presented facts indicate that, around the $1930 \mathrm{~s}$, Ebre Observatory, following its commitment to solar-terrestrial physics, was ready to start some ionospheric studies. The reasons why this did not happen right away are purely non-scientific. The political instability in Spain was growing in the beginning of the 20th century. In 1931 the monarchy was abolished and the republic was proclaimed. The Society of Jesus was forbidden in Spain. Recognizing their outstanding work, the Jesuits in charge of the Ebre Observatory were allowed to continue their work as individuals, but the Observatory lost a significant part of the operating funds. Later, the Spanish Civil War (1936-39) posed a serious threat to the continuity of the Ebre Observatory. It is obvious that during these years all efforts at the Observatory were devoted to secure its continuity and, indeed, its physical survival. Probably this is the reason why we cannot find any reference to the necessity of installing an ionospheric sounder at the Observatory or any plans pointing openly to ionospheric studies.

But scientific activities continued after the Civil War. Antoni Romañá (1900-1981) took over the direction of the center and the Ebre Observatory became associated with the Consejo Superior de Investigaciones Científicas - CSIC (Spanish Research Council) allowing the collaboration of the Spanish State in reconstructing the center. At that moment, Ebre Observatory had already realized the necessity to incorporate instruments to study the ionosphere, but the initial priority was to reinstall all previously existing instruments and to reactivate the series of observations. The Second World War interfered due to the lack of international cooperation and economic resources. After WWII, Spain was sanctioned by the United Nations for her previous collaborations with fascist regimes, and exclusion of Spain from international scientific 
organizations was proposed. In fact, Romañá, using his personal prestige and that of the Ebre Observatory played an important role to overcome this situation. Given the circumstances, it was not the best moment to start new developments.

During these years, Ebre Observatory remained involved in the characterization and study of rapid variations. In fact, since 1954 until now, Ebre Observatory has been in charge of the IAGA rapid variations bulletin. Moreover, Romañá was in charge of organizing several special workshops on rapid variations, especially the workshops held in Copenhagen and Utrecht. The main scientific contribution of this involvement was the beginning of the publications of "Sudden Commencements and Solar-Flare Effects" (Romañá et al., 1955), which continued up to now in different formats, and the two versions of the "Provisional Atlas of Rapid Variations" ([Romañá et al., 1958] and [Romañá et al., 1959]).

Coming back to ionospheric research, it is possible to follow the awareness of Romañá during those years about the importance of ionospheric research at the Observatory by looking at the many references to it, especially to the "fading" problem introduced in its speech about recent progress in solar research (Romañá, 1945), or by reviewing the many pages devoted to it in the Ph.D. thesis of Princep (1949), done under his supervision. When international cooperation became available again, around 1950, the Ebre Observatory engaged again in plans to establish an ionospheric section.

\section{The ionospheric section}

We find the first direct plans to create an ionospheric section at Ebre Observatory when, in 1952, E. Galdón, a member of the Ebre Observatory staff, together with Romañá attended the URSI meeting held in Sidney, Australia and presented the Spanish application for membership in the Union, which was accepted. Other indications are found on the occasion of the solar eclipse of 25 February 1952, observable from Equatorial Guinea, at that time a Spanish colony, and other countries in equatorial Africa. Some Spanish institutions, Ebre Observatory among them, prepared a scientific expedition to study it. Ebre Observatory already envisioned the possibility of acquiring a vertical ionospheric sounder for this occasion to cooperate in the study of the solar eclipse (Romañá, 1953); but it was impossible to meet the deadline. But efforts continued and soon a new vertical ionospheric sounder, the first one installed in the lberian Peninsula (the nearest ones were at Poitiers, France, and Rabat, Morocco), arrived at the Ebre Observatory. It was at the end of 1954, just in time for collaboration in the International Geophysical Year projects. Beginning at that time, a new ionospheric section joined those already existing at the observatory. The installation of the instrument was accompanied by preliminary studies to define its use in solar-terrestrial research (Cardús, 1955) on the theoretical basis of the study of the ionosphere (Galdón, 1959). The short treatise on magnetoionic theory written by Galdón (1959) is the first one published in Spanish. 
The first ionograms were recorded in March 1955 by the French sounder ST35. The instrument (with a range 1.4-16 MHz) is described in Cardús (1955). An ionogram example is depicted in Fig. 1. This sounder was replaced by a Swedish one from "Magnetic AB" in 1967 (0.25$20 \mathrm{MHz}$ ) that was running until 1987. With the help of Prof. Bodo Reinisch of the University of Massachusetts Lowell, a Digisonde 256 was installed in 1988, which is still in operation today. To complete the set of instruments at the observatory, a new recorder for "atmospherics" ( $f=27 \mathrm{KHz}$ ) was added in 1957. As discussed later, a radio-absorption recording system based on the A3 method was installed in 1967 as well.

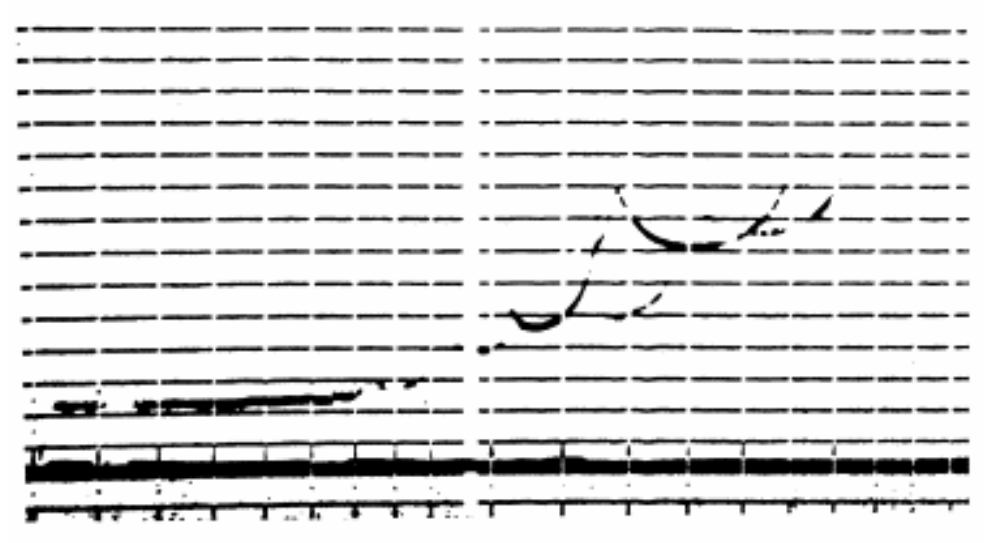

Fig. 1. Example of one of the firsts ionograms recorded with the sounder ST-35 installed at Ebre, particularly the one recorded on April 17 at 13:00 UT. Note the linear scale of virtual height axis $(y)$ against the logarithmic scale on frequency axis $(x)$.

Since the preliminary studies of Cardús (1955) and Galdón (1959), the Ebre observatory has been contributing regularly to monitor and study the ionosphere. The contribution of Ebre Observatory to ionospheric studies has recently been reviewed by Alberca et al. (2000) and here we only summarize the results presented in this previous work, which is written in Spanish.

From the late 50 s to the early 60 s, the ionospheric studies at the Ebre Observatory were based on the knowledge of the temporal variations of the regular layers (E, F1 and F2) and of the sporadic layers (Es), based on studies of their critical frequencies (Cardús, 1958). Also, Es layer studies were a target of a joint CONIE-NASA-CNES project that included rocket launches (Galdón et al., 1981). Some of the results on the probability of Es layer occurrence (Fig. 2) are a current topic. 

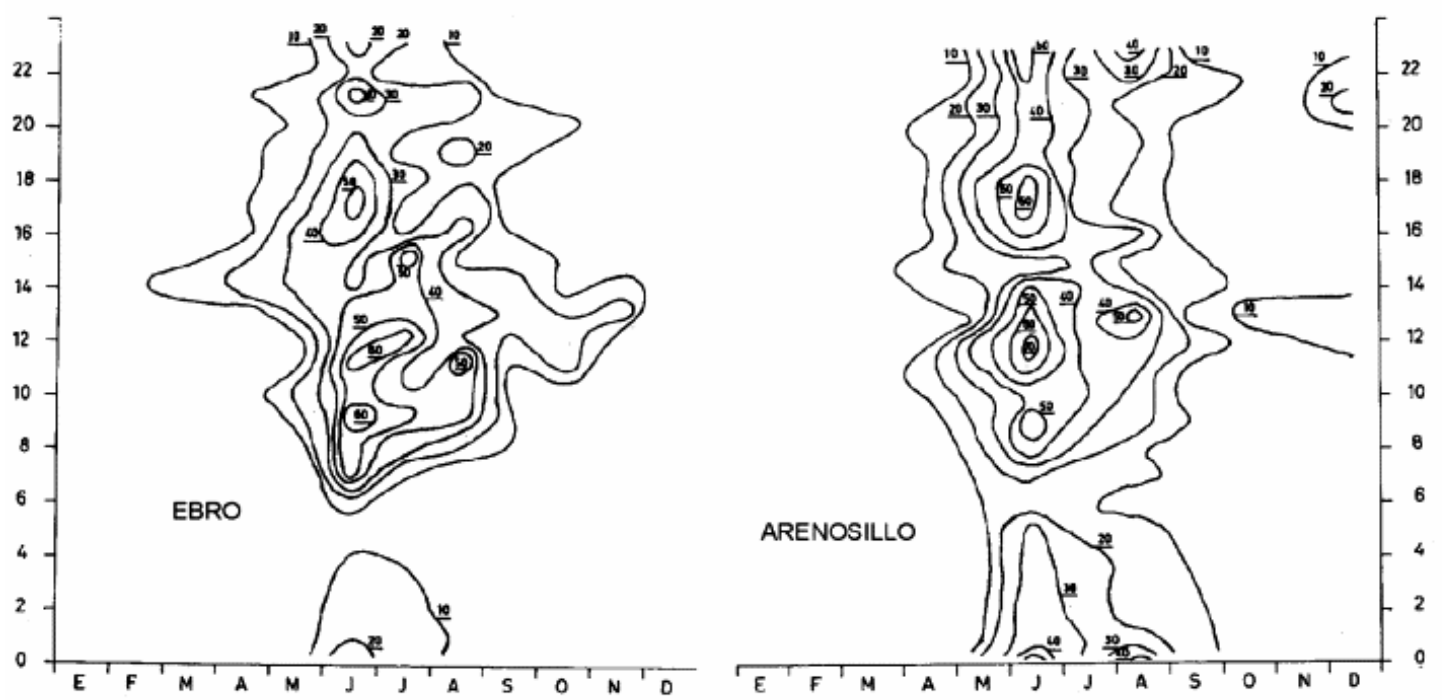

Fig. 2. Contour maps corresponding to the percent of cases for which $f_{0} E_{\mathrm{s}}$ is above $5 \mathrm{MHz}$ as function of month and local time during 1974. Left-plot is for Ebre $\left(40.8^{\circ} \mathrm{N}, 0.5^{\circ} \mathrm{E}\right)$ and right one for El Arenosillo $\left(37.1^{\circ} \mathrm{N}, 353.2^{\circ} \mathrm{E}\right)$ ionospheric stations. Figure adapted from Galdón and Alberca (1976).

However, more important results were obtained in the late 60 s and $70 \mathrm{~s}$. These were related to total electron content (TEC) and D region radio absorption studies. In 1964 NASA launched the Explorer 22 satellite and later provided recording equipment for Faraday rotation TEC measurements at Ebre Observatory. In the following years, data from satellites Syncon III, Intelsat II-F3, ATS-F, SIRIO, and INTASAT were also recorded and used. Daily and seasonal behavior of TEC, and solar activity influence on TEC were obtained and assessed ([Cardús, 1966], [Galdón, 1968], [Galdón and Alberca, 1970a], [Galdón and Alberca, 1971] and [Alberca and Galdón, 1974]): in general, the winter anomaly does not exist in the TEC recorded at Ebre Observatory (Galdón and Alberca, 1970b), (Fig. 3). A combination of TEC and vertical incidence soundings allowed for studies of the ionospheric slab thickness (Galdón, 1970), and some other parameters such as neutral temperature, scale height, and integrated electron production rate for vertical and grazing incidence (Fig. 4) were also deduced (Alberca, 1977). Note that even today there are significant contributions to IRI modeling on slab thickness and scale height behavior.

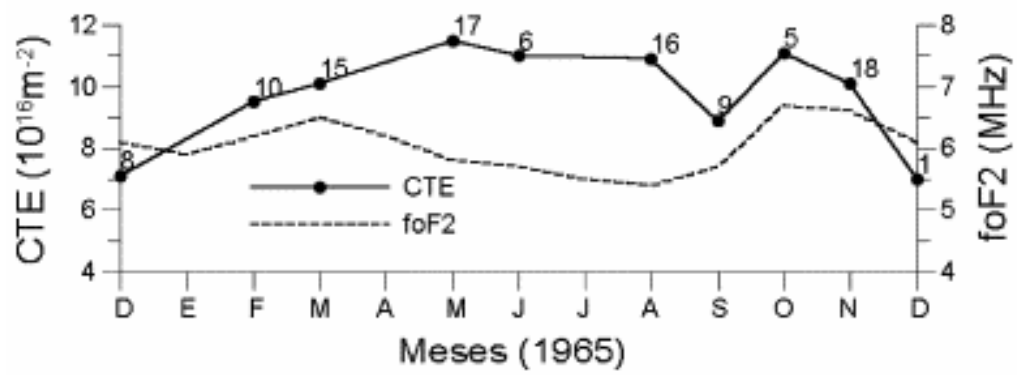


Fig. 3. Annual variation of the monthly averaged Total Electron Content (CTE) and of $f_{0} F_{2}$ around midday (10-14 UT) during 1965 above Ebre. Figure adapted from Galdón (1968).
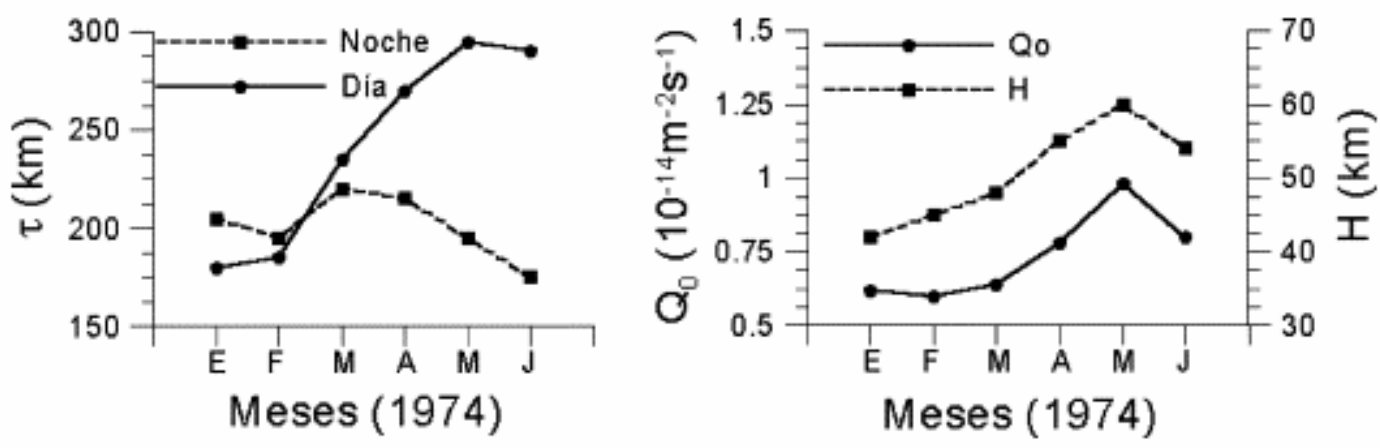

Fig. 4. Variation of the daytime and nighttime averaged values of the slab thickness $T$ (left), and of the scale height $H$ and of the production velocity $Q_{0}$ at sunset (right) during 1974. Figure adapted from Alberca and Galdón (1974).

In 1967 collaboration between the Ebre Observatory and the Max-Plank Institut für Aeronomie in Lindau, Germany began in order to establish a network of radio absorption measurements, covering the Iberian Peninsula, that were based on the A3 method (Rose et al., 1971). As a result of this joint effort, the winter anomaly of the $D$ region was assessed, and these studies were complemented by measurements of temperature, composition, and wind velocity at $D$ and E heights by means of rocket launches (Galdón et al., 1974).

During the 1980s there was a noticeable lack of ionospheric research at the Ebre Observatory, probably because of economic difficulties. Fortunately, during the early 90 s new collaborations started with researchers from abroad, and the Ebre Observatory invested in "young scientists" to continue its tasks. The participation of the Ebre Observatory in the European COST actions 238 and 251 were crucial. It was discovered that a hysteresis variation of the foF 2 with sunspot cycle was related to a semi-annual geomagnetic wave (Apostolov and Alberca, 1995), and a model for its prediction was proposed by Apostolov et al. (1994). A model of the ionospheric currents in the $E$ layer, responsible for the diurnal geomagnetic variation, was developed (Torta et al., 1997). Related to ionospheric predictions, a model based on the Australian ionospheric index T and on the geomagnetic activity index Ap (Sole, 1998) has been selected as the best single station prediction model for monthly median values of foF2 for the COST 251 action. Also, the variability of the ionospheric $\mathrm{F}$ region, caused by planetary wave signatures and its relationship to mesosphere/lower thermosphere winds and geomagnetic activity variations, has been extensively investigated ([Pancheva et al., 1994], [Apostolov et al., 1998], [Altadill, 2000] and [Altadill and Apostolov, 2003]). 
More recent studies obtained the long-term variation of foF2 caused by the 27-day geomagnetic activity recurrences (Apostolov et al., 2004) and F1 region effects of geomagnetic storms ([Buresova et al., 2002] and [Buresova et al., 2004]). Several papers on IRI parameters modeling and on ionospheric characteristics and their variability are published in this issue.

In parallel with this scientific task, the Ebre Observatory contributed regularly to the World Data Centers with data from vertical incidence soundings from 1955 up to today, although there are some data gaps (Lincoln, 1983).

\section{Summary and concluding remarks}

Research of the solar-terrestrial environment was an early objective of the Observatori de l'Ebre starting operation in 1904. In 1955 the ionospheric section was formed at Ebre and contributed to knowledge manifested in Earth's ionosphere. The main achievements of the ionospheric research at Ebre have been introduced. We have paid special attention to research that started thirty years ago and is still of importance today.

\section{Acknowledgement}

This research has been partly funded by Spanish DGI project HUM2004-04259/HIST.

\section{References}

Alberca, 1977 L.F. Alberca, lonospheric electron production rate for grazing incidence at the Ebro Observatory, Urania 287-288 (1977), pp. 41-90.

Alberca and Galdón, 1974 L.F. Alberca and E. Galdón, Some results of electron content measurements at Tortosa from the Intelsat II-F3 transmissions, Sci. Rep. 5 (1974).

Alberca et al., 2000 L.F. Alberca, D. Altadill, J.G. Solé, E. Galdón and E.M. Apostolov, Contribución del observatorio del Ebro al estudio de la ionosfera terrestre (in Spanish), Física de la Tierra 12 (2000), pp. 13-39.

Alberca and Torta, 2002 L.F. Alberca and J.M. Torta, Some Historical Highlights of the Ebro Observatory, Beiträge zur Geschichte der Geophysik und Kosmischen Physik, III, Heft 2 (2002), pp. 226-241.

Altadill, 2000 D. Altadill, Planetary wave type oscillations in the ionospheric $\mathrm{F}$ region, $A d v$. Space Res. 26 (8) (2000), pp. 1287-1296.

Altadill and Apostolov, 2003 D. Altadill and E.M. Apostolov, Time and scale size of planetary wave signatures in the ionospheric $\mathrm{F}$ region: role of the geomagnetic activity and mesosphere/lower thermosphere winds, J. Geophys. Res. 108 (A11) (2003), p. 1403.

Apostolov and Alberca, 1995 E.M. Apostolov and L.F. Alberca, foF2 hysteresis variations and the semi-annual geomagnetic wave, J. Atmos. Terr. Phys. 57(7) (1995), pp. 755-757. 
Apostolov et al., 1998 E.M. Apostolov, D. Altadill and R. Hanbaba, Spectral energy contributions of quasi-periodic oscillations (2-35 days) to the variability of the foF2, Ann. Geophys. 16 (2) (1998), pp. 168-175.

Apostolov et al., 2004 E.M. Apostolov, D. Altadill and M. Todorova, The 22-year cycle in the geomagnetic 27-day recurrences reflecting on the F2-layer ionization, Ann. Geophys. 22 (2004), pp. 1171-1176.

Apostolov et al., 1994 E.M. Apostolov, D. Pancheva and L.F. Alberca, Long-term prediction of the foF2 on the rising and falling parts of the solar cycle, Adv. Space Res. 14 (12) (1994), pp. 47-50.

Balcells, 1908 Balcells, M. L'Observation Solaire, Mémoires de l'Observatoire de l'Ebre, no. 2, Barcelona, Gustavo Gili, 135 pp. + 8 pl., 1908 (in French).

Bauer, 1922 L.A. Bauer, Some results on recent Earth-current observations and relations with solar activity, terrestrial magnetism, and atmospheric electricity, J. Terr. Magnet. Atmos. Electr. 27 (1922), pp. 1-30.

Bauer, 1924 L.A. Bauer, Correlations between solar activity and atmospheric electricity, J. Terr. Magnet. Atmos. Electr. 29 (1924), pp. 23-32 (161-186).

Bauer, 1925 L.A. Bauer, Regarding atmospheric electricity and its relation with solar activity, J. Terr. Magnet. Atmos. Electr. 30 (1925), pp. 17-23.

Batlló, 1995 J. Batlló, L’Observatori de l'Ebre, Revista de Física 1 (8) (1995), pp. 41-46 in Catalan.

Batlló and Roca, 2005 J. Batlló and A. Roca, L'any dels observatoris, Revista de Física 3 (9) (2005), pp. 44-50 in Catalan.

Buresova et al., 2002 D. Buresova, J. Lastovicka, D. Altadill and G. Miró, Daytime electron density at the F1-region in Europe during geomagnetic storms, Ann. Geophys. 20 (2002), pp. 1007-1021.

Buresova et al., 2004 D. Buresova, D. Altadill, M. Mosert and G. Miró, Predicted and measured bottomside F- region electron density and variability of the D1 parameter under quiet and disturbed condition over Europe, Adv. Space Res. 34 (9) (2004), pp. 1973-1981.

Cardús, 1955 J.O. Cardús, Sondeos ionosféricos, Rev. Geofísica 14 (56) (1955), pp. 285-312 in Spanish.

Cardús, 1958 J.O. Cardús, Variaciones de las capas ionosféricas. Aplicación a Tortosa, Rev. Geofísica 16 (1958), pp. 121-148 in Spanish.

Cardús, 1966 J.O. Cardús, Variaciones del Contenido total de electrones en la lonosfera deducidas de Observaciones del satélite S-66, Urania 51 (264) (1966), pp. 187-223 in Spanish. Cardús, 1983 Cardús, J.O. El Observatorio del Ebro, Contribuciones científicas para conmemorar el 75 aniversario del Observatorio del Ebro, in: J.O. Cardús (Ed.), Memoria num. 14, Publicaciones del Observatorio del Ebro, Roquetes, pp. 9-19, 1983 (in Spanish). Cirera, 1906 Cirera, R. Notice sur l'Observatoire et sur quelques observations de l'éclipse du 30 Août 1905, Mémoires de l'Observatoire de l'Ebre, no. 1, Barcelona, Gustavo Gili, 59 p. + 12 pl., 1906 (in French). 
Cirera et Balcells, 1907 R. Cirera and M. Balcells, Étude des rapports entre l'activité solaire et les variations magnétiques et eléctriques enregistrées à Tortose (Espagne), Comptes Rendus des Séances de l'Académie des Sciences 144 (18) (1907), pp. 959-961.

Coulomb, $1983 \mathrm{~J}$. Coulomb. L'Observatoire de l'Ebre et les Organisations Scientifiques Internacionales, Contribuciones científicas para conmemorar el 75 aniversario del Observatorio del Ebro. Memoria num. 14, in: J.O. Cardús (Ed.), Publicaciones del Observatorio del Ebro, Roquetes, pp. 41-46, 1983 (in French).

Galdón, 1959 E. Galdón, Estudio de la ionosfera por sondeos de incidencia vertical, Urania 44 (249) (1959), pp. 1-120 in Spanish.

Galdón, 1968 Galdón, E. Daily and Seasonal Variation of the Total Electron Content of the Ionosphere over Tortosa, in: Addendum, Oslo, (Ed.),"Joint Satellite Studies Group, Report N ${ }^{\circ}$ 3". by Auroral Observatory. Tromso (Norway), pp. 84-107, 1968.

Galdón, 1970 E. Galdón, Study of the total electron content and slab-thickness of the ionosphere at Tortosa, Urania 55 (271-272) (1970), pp. 208-228.

Galdón and Alberca, 1970a E. Galdón and L.F. Alberca, Solar activity and total electron content correlation in the ionosphere at Tortosa, Urania 55 (271-272) (1970), pp. 229-240.

Galdón and Alberca, 1970b E. Galdón and L.F. Alberca, Influence of the solar cycle variations of the total electron content of the ionosphere over Tortosa, Radio Sci. 5 (6) (1970), pp. 913915.

Galdón and Alberca, 1971 E. Galdón and L.F. Alberca, Seasonal and solar cycle variations of total electron content at temperate latitudes, Urania 56 (273) (1971), pp. 110-121.

Galdón et al., 1974 E. Galdón, G. Rose, J. Weber and H.U. Widdel, Experimental results of radio wave absorption measurements in Southwest Europe. In: K. Rawer, Editor, Methods of measurements and results of Lower lonosphere Structure, Akademie Verlag, Berlin, Germany (1974), pp. 331-340.

Galdón and Alberca, 1976 E. Galdón and L.F. Alberca, Comparación de los Datos Ionosféricos Obtenidos en el Observatorio del Ebro y en el Arenosillo. II.-Capa Es, II As. Nacional de Geodesia y Geofísica, Barcelona, v. II (1976), pp. 1335-1351.

Galdón et al., 1981 E. Galdón, J.O. Cardús, L.F. Alberca, A. Salvador, C. Sidi and H. Teitelbaum, El viento neutro y la formación de la capa E esporádica, I Sym. Nac. URSI (1981), pp. 387-390.

García Mollà, 1909 García Mollà, J. La Section Électrique, Mémoires de l'Observatoire de l'Ebre, no. 4, Barcelona, Gustavo Gili, 126 pp. + 6 pl., 1909 (in French).

Lincoln, 1983 Lincoln, J.V. Use of Ebro Observatory Data at World Data Center A for SolarTerrestrial Physics, Contribuciones científicas para conmemorar el 75 aniversario del Observatorio del Ebro, J.O. Cardús (Ed.), Memoria num. 14, Publicaciones del Observatorio del Ebro, Roquetes, pp. 47-48, 1983.

Merveille, 1908 Merveille, P.E. La Section Magnétique, Mémoires de l'Observatoire de l'Ebre, no. 3, Barcelona, Gustavo Gili, 75 pp., 1908 (in French). 
Nippoldt, 1904 A. Nippoldt, On the investigation of simultaneous occurrences in the solar activity and terrestrial magnetism, Astrophys. J. 20 (1904), pp. 202-206.

Pancheva et al., 1994 D. Pancheva, L.F. Alberca and B.A. de la Morena, Simultaneous observation of the quasi-two-day variations in the lower and upper ionosphere over Europe, $\mathrm{J}$. Atmos. Terr. Phys. 56 (1) (1994), pp. 43-50.

Princep, 1949 J.M. Princep. Bahías geomagnéticas, Memorias del Observatorio del Ebro, No. 10, Tortosa, Publicaciones del Observatorio del Ebro, 124 p., 1949.

Puig, 1931 I. Puig, Le gradient de potential atmosphérique a l'Observatoire de l'Ebre (19101930), Gerlands Beiträge zur Geophysik 33 (1931), pp. 338-350 in French.

Rodés, 1922 L. Rodés, On the non-simultaneity of magnetic storms, J. Terr. Magnet. Atmos. Electr. 27 (1922), pp. 161-166.

Rodés, 1927a L. Rodés, Some new remarks on the cause and propagation of magnetic storms, J. Terr. Magnet. Atmos. Electr. 32 (1927), pp. 127-131.

Rodés, 1927b L. Rodés, El Firmamento, Salvat Editores, Barcelona (1927) iv + 585 pp.

Rodés, 1932 Rodés, L. Período diurno anual y secular en las perturbaciones súbitas del campo magnético terrestre. J. Terr. Magnet. Atmos. Electr., 37, 273-278, 1932 (also published as:

Diurnal, annual and secular periodicity in the sudden perturbations of the geomagnetic field, Defense Research Board Translations; T1 SP. - 1959).

Rodés, 1933 L. Rodés, Acción del Sol en el gradiente del potencial eléctrico de la atmósfera y en las perturbaciones súbitas del campo magnético terrestre, Memorias de la Real Academia de Ciencias y Artes de Barcelona 23 (11) (1933), pp. 239-251.

Rodés, 1939 L. Rodés, El Firmamento (2nd edition.), Salvat Editores, Barcelona (1939) viii + 689 pp.

Romañá, 1945 A. Romañá, Recientes progresos en nuestro conocimiento del sol y su influjo en los fenómenos geofísicos, Asociación Española para el Progreso de las Ciencias, XVIII Congreso, Córdoba (1945), pp. 125-153.

Romañá, 1953 A. Romañá, Expedición a Guinea para la observación del eclipse total de Sol de 25 de febrero de 1952, Urania 38 (234) (1953), pp. 175-187.

Romañá et al., 1955 A. Romañá, J. Bartels and J. Veldkamp, International data on magnetic disturbances, part I: sudden commencements and solar-flare effects. Preliminary report, J. Geophys. Res. 60 (1955), pp. 351-354 525-527, 1955.

Romañá et al., 1958 A. Romañá et al., Provisional atlas of rapid variations: IAGA committee on rapid variations and earth, Currents, Tortosa 20 (1958).

Romañá et al., 1959 Romañá, A. et al. IAGA Symposium on Rapid Variations, Provisional Atlas of Rapid Variations, in: Annals of the Internat. Geophys. Year, 2B, pp. 668-709, 1959.

Rose et al., 1971 Rose, G., Schubart, W., Weber, J., Widdel, H.U., Galdón, E. Ergebnisse von Bondenmessungen der Kurzwellenabsorption in Spain, Kleinheubacher Berichte, Band Nr. 14, 239-246, 1971. 
Solé, $1998 \mathrm{~J}$. Solé, Relation between hourly monthly median values of foF2 and some geophysical indices. Its application to an ionospheric single station model, Acta Geophys. Polonica 46 (1998), pp. 77-88.

Torta et al., 1997 J.M. Torta, J.J. Curto and P. Benze, Behavior of the quiet day ionospheric current system in the European region, J. Geophys. Res. 102 (1997), pp. 2483-2494.

Udias, 2003 A. Udias, Searching the heavens and the earth: the history of Jesuit observatories, Kluwer Academic Publishers, Dordrecht (2003) xiii+369. 